\title{
A Case Study of Pre-service English Teachers' Autonomous Learning in Practicum: the Activity Theory Perspective*
}

\author{
Qi Feng \\ Foreign Languages School \\ Northeast China Normal University \\ Changchun, China
}

\begin{abstract}
Research shows that internal factors like learner's motivation, self-efficacy and achievement attribution greatly affect autonomous learning. This study focuses on the external factor to explore how curriculum affects autonomous learning. The study observed and interviewed four pre-service English teachers during their practicum where practiceoriented curriculum for practicum is implemented. The study found that curriculum regulates pre-service English teachers' autonomous learning in arousing their awareness of autonomous learning and develop the ability to learn autonomously.
\end{abstract}

Keyword—autonomous learning; pre-service English teacher; activity theory

\section{INTRODUCTION}

Autonomous learning has been an important issue in foreign language teaching since it is significantly correlated with learners' achievements. Learners are the most discussed factors that affect autonomous learning acquisition (Benson, 2011). Learners' motivation, self-efficacy and achievement attribution determine learning process and result (Spratt, Humphreys \& Chan, 2002). Except these internal factors, external factors are seldom explored in China. Therefore, focusing on practicum plan, which is also curriculum plan when practicum is treated as a curriculum of practice nature, this study explores how curriculum affects pre-service teachers' autonomous learning. This study is carried out in Northeast China normal university (NENU), where practiceoriented practicum plan is implemented with the purpose of training excellent pre-service teachers. The study finds that curriculum regulates pre-service English teachers' autonomous learning in arousing their awareness of autonomous learning and develops the ability to learn autonomously.

\section{THEORETICAL FRAMEWORK}

Activity Theory was developed in early twentieth century by scholars of Russian cultural-historical school of psychology. Engestrom, an important contributor of activity theory worked out an activity theory model (Engestrom, 1987). There are 6 components in this model, which are subject, and object, the tools, community of significant others, the rules, and the division of labor.

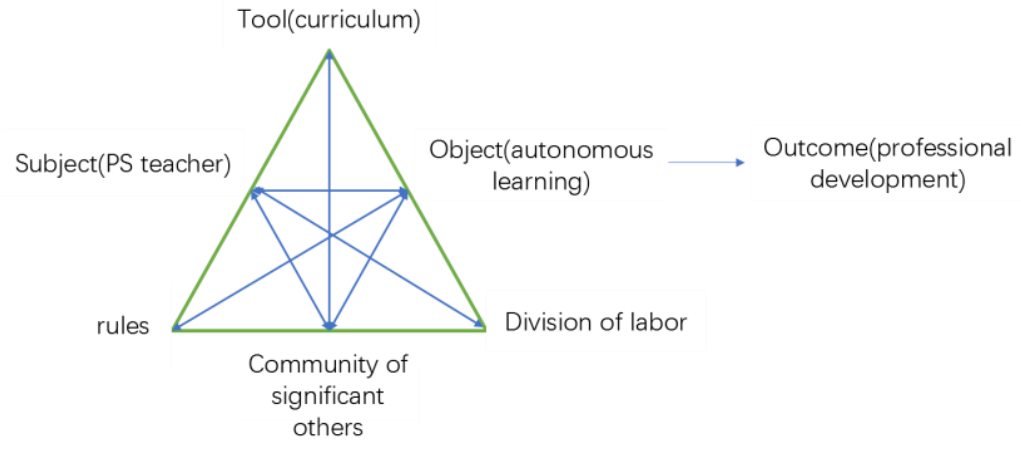

Fig. 1. Adapted activity theory model.

The tools, either material or conceptual, are what employed by the subject to act on the object or to pursue the

*The study is supported by Jilin Province Education Science Fund (No ZD16007), and Jilin Province Ministry of Education Social Science Fund (No. JJKH20180055SK) desired outcome. Members in community of significant share the same interest in the object with the subject and they work together with the subject on the object. Rules and the division of labor mediate the relations between the subject and the community. Rules regulate the subject's action and 
the relations with other members of the community. The division of labor includes both division of tasks and division of power and resources.

This study adapts activity model, making it specific to the present research context in "Fig. 1".

\section{PRACTICE-ORIENTATED CURRICULUM}

Practice-orientated curriculum in NENU aims at furthering pre-service teachers' understanding of pedagogy theory, and generating practical knowledge needed in teaching.

The curriculum is composed of tasks, support activities, evaluation standard and evaluation activities. Pre-service teachers should fulfill certain tasks during the practicum. These tasks are arranged weekly. Mentors provide support of various forms like school workshop, weekly plan, class observation conference, experience sharing conference, professional conversation. These support activities are held regularly. Pre-service teachers evaluate themselves by using standard when a task is finished, and they receive evaluation from mentors as well. Mentors' choice of support form is based on the result of evaluation, and whether support is effective is illustrated by evaluation.

The curriculum carries following features:

A. pre-service teachers decide their own learning plans self-directedly. It is pre-service teachers rather than mentors who decide the field to develop.

B. reflection is stressed. Curriculum provides opportunity for pre-service teachers to conduct professional conversation; there are evaluation feedback for pre-service teachers; preservice teachers write reflection journals.

C. professional development is based on targets. Preservice teachers evaluate their qualities as teachers according to standard, and then make development plan.

\section{RESEARCH QUESTIONS}

- What is Pre-service English Teacher's Autonomous Learning Experience?

- Does curriculum affect pre-service English teacher's autonomous learning? If yes, in what way?

\section{METHODOLOGY}

The study has observed and interviewed four pre-service English teachers in NENU during their eight-week practicum.

- Participants: The participants are four pre-service English teachers, with their names Mendy, Diana, Rose and Jessie. They have finished courses on English language and language teaching in the first six terms in the university. They start their practicum in the seventh term. During the practicum, they will teach independently with the guidance of mentors and observe others' class.
- Data collection: Data collection tools are observation and interview. The researcher as mentor assistant observed the participants during the eight weeks. The venues for observation are participants' classroom, teaching seminar, experience sharing conference and after-observation conference. The researcher observed and videoed participants' teaching, with the total length of 270 minutes per person, their conversations with peer teachers and mentors in three teaching seminars, experience sharing conferences and after-observation conferences, with the total length of 400 minutes per person.

The research interviewed the four participants after their teaching and attending teaching seminar, experience sharing conferences and after-observation conferences. Each interview length is 20-40 minutes, which depends on participant's schedule and will.

- Data analysis: The study employs Cresswell's qualitative data analysis framework (Creswell, 2009). The researcher first transcript videos and get a text of 100 thousand words. The researcher then read the text to have a general idea and reflect the meaning of data. The third step is coding. The researcher categorized sentences and paragraphs and name the categories. The last step is to generate theme. The researcher compared and filtered data, and then got the themes: learning process, task, reflection, support.

\section{RESEARCH FINDINGS}

\section{A. Autonomous Learning of Pre-service English Teachers Is a Cycle of "Plan-action-reflection-adjustment"}

Pre-service English teachers are informed the purpose and the requirements of practicum at the very beginning. They make weekly plan with reference to practicum targets and requirements, which help them avoid blindness in practice.

I understand what I should do in practicum after I read the handbook. Besides, what qualities a teacher should have are also presented here. I can check with this standard to see the level I am on (Rose).

Teaching independently is totally different from class observation. When you observe others, you just look at and listen to the teacher. While teaching independently means you are the leading actor, and you are responsible for selecting and arranging teaching contents. I just make plan according to the task requirements in practicum handbook. This is not so easy (Rose).

Making plan makes my practicum effective. Because of the plan, I know what to reflect and useful strategies are strengthened. I will not react to the plight spontaneously, and then forget the strategy I used. This helps me accumulate useful strategies (Jessie).

After carrying out study plan, pre-service English teachers reflect the rationality and effectiveness of the study plan. Concept renovation brought about by reflection 
produces new actions. If action strategies in the study plan achieve satisfying consequence, the strategies are strengthened. If not, pre-service English teachers will adopt new strategy to adjust their action.

My weekly plan is "to enhance students' interest in English learning". The strategy I used is to engage students in discussing about the topic related to this unit. I think it is satisfying. Students understood what we are going to cover in the unite and I introduced the language points naturally in discussion. Everything is natural. I believe I can use this strategy in the following units. I don't need to beat my brains out when design how to begin a new unit (Diana).

In order to help my students learn phrases related to "come", I design a game "the faster, the better". Students orally translate the phrases on the screen as quickly as they can. The winners are the fastest. But in class I found the classroom was in a mass. Some students were talking with each other, some just cheered for others, but they themselves did not engage in it. I think it is because the design is beyond student's language level, so some of them can not engage in this activity. So what to do to solve this? I haven't got a good idea (Mendy)

\section{B. Autonomous Learning of Pre-service English Teacher Is Regulated by Curriculum}

Curriculum affects autonomous learning of pre-service English teachers. It is under the curriculum that pre-service English teachers learn autonomously. Specific requirements of practicum tasks set by curriculum help pre-service English teachers clarify their practicum target. Support activities according with tasks guide pre-service English teachers to control their learning. Of the support activities, weekly plan and professional conversation take regulating functions greatly.

1) Weekly plan: In order to help pre-service teachers understand their achievements and disadvantages, curriculum requires pre-service English teachers make weekly plan during the practicum. The weekly plan includes weekly target and action strategies.

With reference to the evaluation standard, pre-service English teachers choose weekly target individually or with the help of mentors. According to the weekly target, they make action strategies. Pre-service English teachers carry out the weekly plan and reflect on the achievement. They report their progress on the weekly experience sharing conferences. Evidences are presented when necessary. Mentors assess the progress according to the evaluation standard and their observation on candidates' performance in class.

This process of making plan, carrying out plan and reflecting plan is autonomous learning process essentially. Pre-service English teachers understand and master steps in autonomous learning.

I prepared the lesson carefully but it proved unsuccessful. I did not realize it was my fault at that time. I thought it was the students who did not cooperate. When I reflected the weekly plan I found my plan is beyond students' level. It is not that they are lazy or naughty, but it is because they cannot understand the task I assigned to them. So I need to find other ways to engage them in leaning (Mendy).

When I met a problem, I just take it as my weekly plan's target. I think it is easy to find directions to develop in this way. You know sometimes it is hard to evaluate yourself and see what to improve. Then I try to find the solution to the problem. If the problem is solved, then it is a good strategy. If the strategy is not effective, then I need to try other strategies. Now I am not anxious when facing problems. I know what to do (Jessie).

2) Professional conversation: Curriculum encourages professional conversations between mentors and pre-service teachers. The contents of professional conversations are about problem solving and sharing education philosophy.

It is natural for pre-service teachers to have confusions and meet problems they cannot solve themselves Professional conversations provide opportunities for preservice teachers to communicate with mentors. Via professional conversations, pre-service English teachers get solutions to problems and further their understanding on teaching if they have strong will to learn to be good teachers.

I like the arrangement. Weekly plan enables me just put focus in one filed. It saves my energy. I do not have energy to cover many fields at one time. None is improved if I cover too many at the same time (Diana).

If I cannot solve the problem, I will go to the mentor. She will provide some good ideas. I will practice the ideas. If there is not the mentor, I don't know how to go on sometimes (Rose).

When I prepared the lesson, I was not sure if I would analyze the text structure, so I did not do that in class. There is another reason for not doing this. I myself was not quite clear about the structure. I talked this with mentor and was told that text organization is one of the most important things in reading lesson. After that, I teach students to analyze organization in each reading class. I can see their progress (Jessie).

\section{Learning Community Provide Professional and Emotional Support for Pre-service English Teachers' Autonomous Learning}

The curriculum requires that pre-service English teachers should interact with peers and mentors to finish practicum tasks. The three parties form learning community through interactions.

Teaching seminar and experience sharing conference are important channels for community members to communicate with and receive support from each other. Pre-service English teachers acquire detailed solutions to teaching problems and at the same time reflect their own learning teaching process in teaching seminar. Listening to others' story in experience sharing conference can provoke response emotionally. Pre-service English teachers may find the plights they meet are common. Seeing their peers are struggling with the same difficulties makes them believe that 
difficulties are not caused by their inability. This delaminates pre-service English teachers' anxiety.

What bothers me is time. I either teach too fast or too slowly to finish the lesson. I discuss with other at seminar. We finally find a good solution. We divide the class into several segments and check time after each segment. We also make a plan B. We prepare some exercises. If time is enough, students will do these exercises, if not, we take it as assignment (Diana).

I was nervous at the beginning. I think I prepared well but when I face the class, I do not know what to say or what to do. I found my accent is not good, and I don't have the carriage a teacher should have, and ... I want to quit. Thanks to experience share conference, I talk this to others and they conform me. I also found I am not the only one who met these problems. Nearly everyone is facing the same thing as me. So, I am not frustrated now (Jessie).

\section{DISCUSSION}

\section{A. Pre-service English Teachers' Autonomous Learning} Ability Is Developed during Interaction with Context

Autonomous learning ability is not inborn, but a result of learners' interaction with context. School culture and curriculum implementation compose the macro environment where pre-service English teachers are. Things and persons in this environment all affect their autonomous learning.

Explicit and implicit teaching principles, school culture, practicum implementation and requirement form constraints for pre-service English teachers, which clash with their will of controlling their own learning. There are meaning negotiations between will of pre-service English teachers and environment during their learning teaching process. Preservice English teachers make use of principles, physical and cultural condition, and interpersonal relationship to realize their leaning target.

Pre-service English teachers sense the requirement and adjust their actions to respond to environment. This adjustment help re-service pre-service English teachers build concept and ability of autonomous learning.

\section{B. Curriculum Should Provide Systematic Support for Pre- service English Teachers' Autonomous Learning}

Autonomous learning is not learning alone but learning with systematic support. At the initial stage of learning to teach, pre-service English teachers need integrate theory and practice in practicum, and develop their practical knowledge. As learning other skills, learning to teach requires professional guide to control learners' action and take charge of their learning, and receive emotional support when encountering difficulties. Even pre-service English teachers of strong autonomous learning will achieve more when systematic support and encouragement are accessible.

The most common support in Chinese universities is to provide solutions when pre-service English teachers meet difficulties. Different from this common practice, support in NENU's practice-oriented curriculum aims to solve specific and long-term problems. Systematic support plays the dual part as to help pre-service English teachers fulfill practicum tasks, and to realize professional development as well.

Support activities enhance pre-service English teachers' teaching performance. Through encouraging pre-service English teachers to reflect their actions, support activities facilitate pre-service English teachers form ability to solve problems independently. A good curriculum should build open environment for pre-service English teachers to observe and analyze their own and peers' teaching. In this environment, pre-service English teachers are encouraged to practice their ideas got in practicum instead of imitating senior teachers.

\section{Autonomous Learning Is a Channel to Realize Professional Development}

Pre-service English teachers' autonomous learning is a process of reflection. They make use of cognitive and emotional ability to decide the limitation and resources in the environment. On the basis of the decision, learning target and action plan are made, with implementation of the plan and evaluation of the achievement followed, which is also realized through reflection.

Reflection enhances teaching performance, but it is not the sole purpose of autonomous learning. Practicum is not mere the process of acquiring correct behaviors, rather reflection process (Brown, Cooney \& Jones, 1990). Preservice English teachers' autonomous learning not only aims at mastering knowledge and skills, but inner power and method for professional growth, which ensures self-guide and continuous development in future career.

\section{Caring for Individual Difference in Pre-service English Teachers' Autonomous Learning}

Pre-service teachers differentiate with each other in learning and teaching. The specific ways of learning to teach varies from person to person. Research from Korthagen also shows that pre-service teachers of introversion tend to learn through reflection, while pre-service teachers of extroversion are inclined to get supports and suggestions from others (Korthagen, 1988). The present study echoes findings of other research that pre-service teachers of different wills view failure in teaching differently. Pre-service teachers with strong wills tend to express their negative emotions, while weak willed pre-service teachers do not communicate with others about their frustration and despair (Leat, McManus, Bramald \& Baumfield, 2015).

\section{CONCLUSION}

Besides internal factors such as motivation and selfefficacy, autonomous learning is affected by external factors as well. Curriculum is one of such external factors, which leads pre-service English teachers' autonomous learning. Practice-oriented curriculum takes regulation function on promoting pre-service English teachers' autonomous learning method and awareness. 


\section{REFERENCES}

[1] Benson, p. (2011). Teaching and Research Autonomy. Pearson Education Limited.

[2] Brown, S. I., Cooney, T. J., Jones, D. (1990). Handbook of research on teacher education. New York: Macmillan.

[3] Creswell, J W. (2009). Research design: Qualitative, quantitative, and mixed methods approaches. Thousand Oaks, California: SAGE.

[4] Engestrom, Y. (1987). Learning by expanding: An activity-theoretical approach to developmental research. Helsinki, Finland: OrientaKonsultit.

[5] Korthagen, F. A. J. (1988). The influence of learning orientations on the development of reflective teaching. Calderhead J. Teachers' professional learning. Philadelphia, PA: Falmer,: 35-50.

[6] Leat, D., McManus, L., Bramald, R., Baumfield, V. (2015). Learning from classroom experience: Some attributes of successful student teachers. Retrieved April 8, 2018, from http://www.facultyfocus.com/articles/philosophy-of-teaching/ninecharacteristics-of-a-great-teacher/

[7] Spratt, M., Humphreys, G., Chan, V. Autonomy and motivation: Which comes first? Language Teaching Research, 2002(6),254-266. 